Soviet-US agreements

\title{
Reagan to review lapsed deals at last
}

Washington

THE Reagan Administration plans to revive six cooperative scientific agreements with the Soviet Union that the United States had allowed to languish in retaliation for the Soviet invasion of Afghanistan, the imposition of martial law in Poland and the shooting-down of the commercial Korean Airlines jet.

The announcement came in a speech last week to participants in a conference on USSoviet relations in which Reagan attempted to walk a fine line - responding to the election-year issue of his administration's failure to ease tensions with the Soviets while at the same time reassuring the conservative faithful that he still believes the Soviet Union to be an "evil empire", as he put it in an earlier speech.

Reagan also announced willingness to re-establish cultural exchanges with the Soviet Union ("what would classical music be without Tchaikovsky", he said) and raised the possibility of a joint US-Soviet space mission intended to develop rescue techniques. An official of the National Aeronautics and Space Administration (NASA) said, however, that nothing had yet been done on "thrashing out the details" of such a mission.

The six scientific agreements that Reagan referred to have never actually expired; however, no new projects have been initiated since President Carter imposed a ban on high-level government contacts after the appearance of Soviet troops in Afghanistan in January 1980. Previously planned activities, such as joint scientific projects, symposia and information exchanges, have continued, but obviously at a much slower pace. The six agreements, all established during the period 1972-74, cover agriculture, health, artificial hearts, environmental protection, oceans and housing. A seventh existing agreement, on atomic energy, was not mentioned by Reagan in his speech or in any background information provided by the White House.

Four other agreements had earlier been allowed to lapse when they came up for renewal; these dealt with space, energy, transportation and an "umbrella", agreement for a series of workshops and studies administered through the National Science Foundation. It is considered not coincidental that these include areas in which the United States has the least to gain through cooperative ventures.

Reagan's effort to show his commitment to "better communications with the people and government of the Soviet Union" comes only a few weeks after the National Academy of Sciences cancelled a planned

visit to the Soviet Union by the academy's president, Frank Press, in the light of uncertainty over the fate of dissident Andrei Sakharov. Press had been urged not to go both by the academy's members and, quietly, by the State Department and by presidential science adviser George Keyworth. Press said that the decision to cancel his visit was consistent with the situation at the time, and that the academy has consistently maintained the importance of keeping open lines of communication with its Soviet counterparts.

Administration officials appear confident that the Soviets will go along with Reagan's proposals on the cooperative agreements. So far, the only tangible action has been on the environmental agreement; at a meeting in

\section{Genetic engineering}

\section{Rifkin strikes at corn this time}

\section{Washington}

THREATENED with becoming the next victim of Jeremy Rifkin's litigious crusade against genetic engineering, Stanford University late last week decided to postpone a planned experiment in which genetically-engineered corn plants would be grown in a test plot.

Stanford had earlier announced that the experiment, the work of Drs Ronald Davis and Virginia Walbot, was not subject to the injunction that halted the Lindow experiment on ice-nucleation bacteria (see Nature 24 May, p.296), and that the corn experiment would proceed this summer. After a call from Rifkin's attorney, Stanford changed its mind. The experimenters said they would voluntarily postpone the tests at least until next year.

The experiment had been approved by the Recombinant DNA Advisory Committee (RAC) of the National Institutes of Health (NIH) in 1981. The plants were to be grown on a test plot separated by a mile on all sides from other cultivated fields, and the corn tassels were to be bagged to prevent spread of the pollen. The experiment would use seed from parent plants that had been injected with a gene coding for the purple colour of Indian corn. The same experiments have been carried out in greenhouses. Unlike bacteria, corn is not self-propagating without human intervention and is not known to spread.

The injunction blocking the Lindow experiment (until a trial on the merits of Rifkin's challenge can be held) also forbade NIH from approving other
Munich earlier last week, Environmental Protection Agency Administrator William Ruckelshaus met Soviet officials and discussed rejuvenating the Joint Environmental Committee, which manages projects under the agreement. Ruckelshaus was named co-chairman, a position that the United States has left vacant since 1980 . (The new-found amity did not, however, prevent Soviet participants at the Munich meeting from claiming that US arms policy was damaging the environment.)

Action on the other five agreements will be taken "in the near future", according to the White House.

Reagan's proposals seem more a change of degree rather than a new initiative. Lowlevel scientific contacts have continued all along, even in areas where agreements have expired. Soviet and US scientists last week, for example, began a joint research cruise in the Pacific to study long-range transport of air pollutants; Soviet scientists have regularly participated in US lunar and planetary symposia, and recently presented results of the Venera 5 and 6 planetary missions. federally-funded experiments involving the release of recombinant DNA to the environment.

The ruling was, however, ambiguous on previously-approved experiments; it said NIH was enjoined from "approving or continuing to approve" deliberate-release experiments. RAC has approved one other federally-funded plant experiment (a Cornell University project involving tomatoes) and one commercial proposal, from Cetus Madison, which is not subject to the injunction.

Rifkin's legal argument is that NIH failed to prepare an environmental impact statement on the "programme" of deliberate-release experiments. If he is successful in the trial, then NIH will be forced to compile such a document, a process that NIH officials say will take at least a year.

Meanwhile, NIH director James Wyngaarden is expected to announce shortly his agreement with Rifkin's demand for "equal" treatment for commercial and federally-funded proposals that come before RAC.

The temporary injunction applied only to the latter, and at its 1 June meeting, RAC approved two deliberate-release experiments submitted by private companies. The effect of Wyngaarden's decision may be to require a formal environmental assessment for commercial proposals, the requirement that Rifkin is demanding in his lawsuit for federallyfunded proposals and from which corporations have been exempt.

Stephen Budiansky 